\title{
Facile Synthesis of Polymer-Supported Cinchona Alkaloid Catalysts for Asymmetric Michael Reaction
}

\author{
Kenjiro Onimura, Kouhei Matsuzaki, Yong-Kyung LeE, Hiromori Tsutsumi, and Tsutomu Oishi ${ }^{\dagger}$ \\ Department of Applied Chemistry and Chemical Engineering, Faculty of Engineering, Yamaguchi University, \\ 2-16-1 Tokiwadai, Ube 755-8611, Japan
}

(Received September 16, 2003; Accepted December 29, 2003)

\begin{abstract}
This article describes the syntheses and polymerizations of new chiral cinchoninyl(2-methacryloyloxyethyl) carbamate (CIMOC) from 2-methacryloyloxyethyl isocyanate (MOI) and cinchonine. Radical homopolymerizations were performed with AIBN as initiator in suitable solvent in a sealed tube at $60^{\circ} \mathrm{C}$. Number average molecular weights $\left(M_{\mathrm{n}}\right)$ of poly(CIMOC) were $2.6-11.8 \times 10^{3}$. Specific optical rotations $\left([\alpha]_{435}\right)$ of poly(CIMOC) were $+84.0^{\circ}$ to $0.72^{\circ}$ in THF. The polymers obtained were tested for their efficiency in catalyzing the Michael addition of ethyl 1-oxo-2-indan carboxylate to methylvinyl ketones. The Michael adducts using poly(CIMOC-co-styrene) showed higher enantio excess (20\%ee) compared to those obtained by using non-polymeric catalyst CIMOC (14\%ee) and poly(CIMOC) (13\%ee).

KEY WORDS Asymmetric Catalyst / Polymer-Supported Catalyst / Optically Active Polymer / Cinchona Alkaloid / 2-Methacryloyloxyethyl Isocyanate / Asymmetric Michael Reaction /
\end{abstract}

Asymmetric synthesis of optically active compounds from prochiral substrate using chiral catalysts is a very attractive methodology in organic chemistry. However, removal of the expensive chiral catalyst from the crude reaction product after the completion of reaction is a tedious job. Polymer-supported catalysts are advantageous, as they can be recovered from the reaction product by simple filtration and can be reused, thus, making the process economically viable. The methodology of attaching chiral ligands onto a polymer has been widely applied to the development of new polymer supported catalysts for asymmetric synthesis. ${ }^{1,2}$ This method may be of importance in the synthesis of the compounds, where selectivity as well as mild reaction conditions is required by simultaneously replacing conventional catalysts with environment-friendly 'green catalysis'.

Cinchona alkaloids such as cinchonine, cinchonidine, quinine, and quinidine, are utilized in a wide variety of asymmetric synthetic processes. Several groups reported polymer-supported cinchona alkaloids. ${ }^{3}$ Copolymerizations of a vinyl group at C-3 in cinchona alkaloids with vinyl monomers such as acrylonitrile or methacrylates were reported to be difficult. ${ }^{4-11}$ But the double bond has no homopolymerizability and low copolymerizability with other vinyl monomers. The authors expect that the introduction of mathacrylate units into cinchona alkaloids would be useful for increasing polymerizability and controlling cooperative interactions between cinchona alkaloids as chiral ligand units and polymer matrix. Introductions of a polymerizable group need mild conditions. Reactions of isocyanates with a hydroxyl or an amino group can readily occur under neutral conditions. Recently, the authors reported facile syntheses and polymerizations of chiral methacrylates obtained from 2-methacryloyloxyethyl isocyanate (MOI) and optically active compounds such as amines ${ }^{12}$ and alcohol. ${ }^{13}$ MOI is a bifunctional monomer with both a reactive isocyanate group and a polymerizable $\mathrm{C}=\mathrm{C}$ double bond.

This article describes a mild and facile procedure of chiral methacrylate polymer obtained from cinchona<smiles>C=C(C)C(=O)OCCNC(=O)OCCOCCO</smiles><smiles>CC(OCCOC(=O)NCCOC(=O)C(C)(C(C)(C)C)C(C)(C)C)C(C)(C)C</smiles>

Asymmetric Michael Reaction Catalyst

${ }^{\dagger}$ To whom all correspondence should be addressed (Tel \& Fax: +81-836-85-9281 E-mail: oishi@yamaguchi-u.ac.jp). 

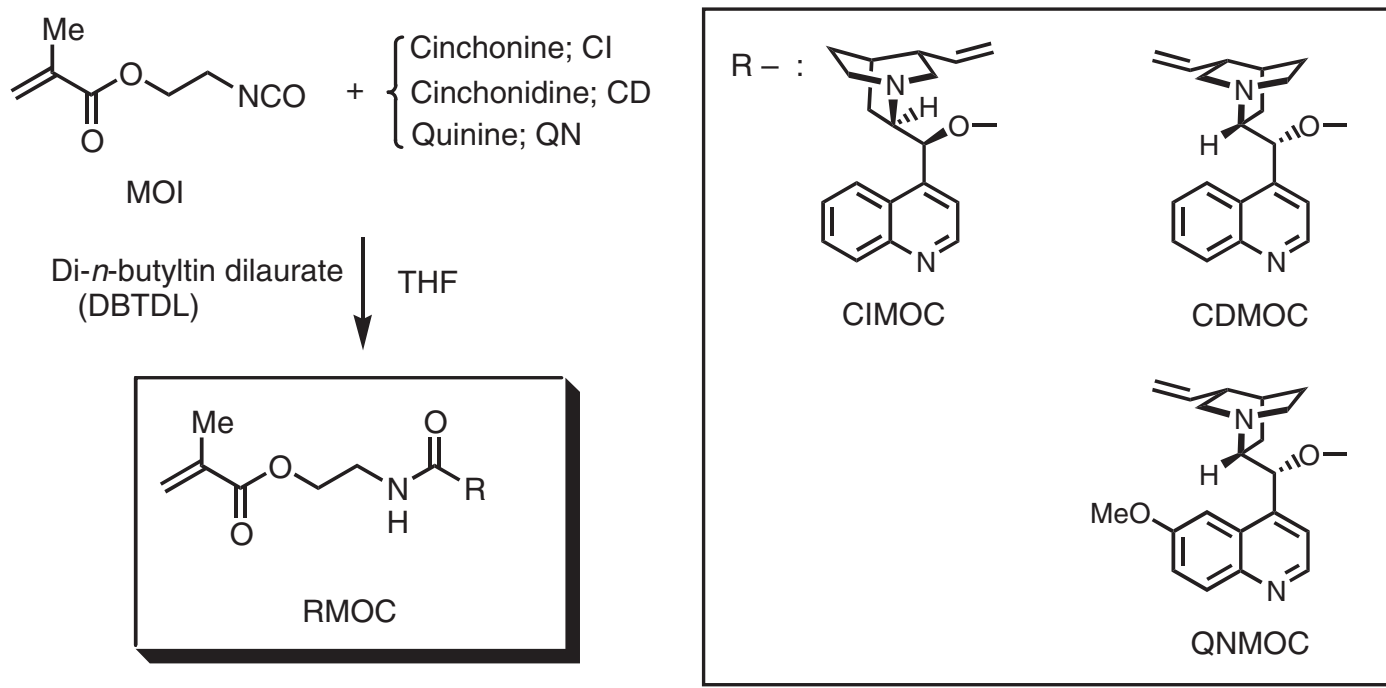

Scheme 2.

alkaloids and MOI, and their application in the asymmetric Michael addition reaction of methylvinylketone (MVK) to $\beta$-ketoester as a chiral catalyst.

\section{EXPERIMENTAL}

\section{Reagents and Solvents}

Commercially available cinchonidine and cinchonine were used without further purification. Solvents, toluene, THF, chloroform and methanol were purified by usual methods. 2-Methacryloyloxyethyl isocyanate (MOI; Showa Denko K.K. Japan) and styrene (St) were distilled and immediately used for polymerization. 2,2'-Azobisisobutyronitrile (AIBN) was purified by recrystallization from methanol.

\section{Monomer}

The synthetic path is shown in Scheme 2 .

\section{Cinchoninyl(2-methacryloyloxyethyl)carbamate (CIMOC)}

MOI (4.50 g, $27.0 \mathrm{mmol}$ ) was added slowly to a solution of cinchonine $(7.80 \mathrm{~g}, 27.0 \mathrm{mmol})$ and di- $n$-butyltin dilaurate (DBTDL) $(0.01 \mathrm{~g}, 0.016 \mathrm{mmol})$ in THF $(80 \mathrm{~mL})$ under nitrogen at r.t., and the solution was stirred for $24 \mathrm{~h}$ at $40^{\circ} \mathrm{C}$. The reaction mixture was evaporated under reduced pressure to give the crude product. Purification by recrystallization from ethyl acetate (EtOAc) $/ n$-hexane (1/1) gave CIMOC as white powder.

Yield 75\%, mp $113-115.8^{\circ} \mathrm{C},[\alpha]_{435}+110.4^{\circ}(c=$ $1.0 \mathrm{~g} / \mathrm{dL}, \quad l=10 \mathrm{~cm}, \mathrm{THF}),{ }^{1} \mathrm{HNMR}\left(\mathrm{CDCl}_{3}\right) ; \delta$ (ppm from TMS) $8.88-7.36(\mathrm{~m}, 6 \mathrm{H}$, in quinoline group), $6.50-6.44(d, 1 \mathrm{H}, J=7.58 \mathrm{~Hz}, \mathrm{O}-\mathrm{CH})$, 6.08-5.99 (m, 2H, $\quad \mathrm{CH}_{2}=\mathrm{C}\left(\mathrm{CH}_{3}\right) \quad$ (trans) and $\left.\mathrm{CH}_{2}=\mathrm{CH}\right), 5.52\left(\mathrm{~s}, 1 \mathrm{H}, \mathrm{CH}_{2}=\mathrm{C}\left(\mathrm{CH}_{3}\right)(\right.$ cis $\left.)\right), 5.19$ $5.06\left(\mathrm{~m}, 2 \mathrm{H}, \mathrm{N}-\mathrm{H}\right.$ and $\left.\mathrm{CH}_{2}=\mathrm{CH}\right), 4.22-4.18(\mathrm{~m}$, $\left.2 \mathrm{H}, \mathrm{COOCH}_{2}\right), 3.48-3.44\left(\mathrm{~m}, 2 \mathrm{H}, \mathrm{CH}_{2} \mathrm{NH}\right), 3.32-$ $3.22\left(\mathrm{~m}, 1 \mathrm{H}, \mathrm{N}-\mathrm{CH}_{2}-\mathrm{CH}_{2}\right.$ (exo)), 3.00-2.86 (m, $2 \mathrm{H}$, $\mathrm{N}-\mathrm{CH}_{2}-\mathrm{CH}$ (exo) and $\mathrm{N}-\mathrm{CH}-\mathrm{CH}_{2}$ ), 2.76-2.65 (m, $2 \mathrm{H}, \mathrm{N}-\mathrm{CH}_{2}-\mathrm{CH}_{2}$ (endo) and $\mathrm{N}-\mathrm{CH}_{2}-\mathrm{CH}$ (endo)), 2.30-2.24 (m, $\left.1 \mathrm{H}, \mathrm{CH}_{2}=\mathrm{CH}-\mathrm{CH}\right), 1.87-1.73(\mathrm{~m}$, $6 \mathrm{H}, \quad \mathrm{CH}_{2}=\mathrm{C}\left(\mathrm{CH}_{3}\right), \quad \mathrm{CH}_{2}-\mathrm{CH}-\mathrm{CH}_{2}, \quad \mathrm{~N}-\mathrm{CH}_{2}-\mathrm{CH}_{2}$ (exo), and $\mathrm{N}-\mathrm{CH}-\mathrm{CH}_{2}$ (exo)), 1.56-1.51 (m, 2H, N$\mathrm{CH}_{2}-\mathrm{CH}_{2}$ (endo) and $\mathrm{N}-\mathrm{CH}-\mathrm{CH}_{2}$ (endo) $)$

${ }^{13} \mathrm{CNMR}\left(\mathrm{CDCl}_{3}\right) ; \delta$ (ppm from TMS) 167.26 $(\mathrm{C}=\mathrm{O}), 155.42(\mathrm{NH}-\mathrm{CO}), 149.90,148.48,145.93$, $130.30,129.08,126.72,125.93,123.41,118.51$ (in quinoline group), $140.56\left(\mathrm{CH}_{2}=\mathrm{CH}\right), 135.74$ $\left(\mathrm{CH}_{2}=\mathrm{C}\left(\mathrm{CH}_{3}\right)\right), \quad 126.09 \quad\left(\mathrm{CH}_{2}=\mathrm{C}\left(\mathrm{CH}_{3}\right)\right), \quad 114.70$ $\left(\mathrm{CH}_{2}=\mathrm{CH}\right), 74.11(\mathrm{O}-\mathrm{CH}), 63.40\left(\mathrm{O}-\mathrm{CH}_{2}\right), 59.66$ $\left(\mathrm{N}-\mathrm{CH}-\mathrm{CH}_{2}\right), 49.71\left(\mathrm{~N}-\mathrm{CH}_{2}-\mathrm{CH}\right), 48.97\left(\mathrm{~N}-\mathrm{CH}_{2}-\right.$ $\left.\mathrm{CH}_{2}\right), 40.33\left(\mathrm{CH}_{2} \mathrm{NH}\right), 39.75\left(\mathrm{~N}-\mathrm{CH}_{2}-\mathrm{CH}\right), 27.75$ $\left(\mathrm{CH}_{2}-\mathrm{CH}-\mathrm{CH}_{2}\right), 26.42\left(\mathrm{~N}-\mathrm{CH}_{2}-\mathrm{CH}_{2}\right), 23.90(\mathrm{~N}-$ $\left.\mathrm{CH}-\mathrm{CH}_{2}\right), 18.21\left(\mathrm{CH}_{3}\right)$.

\section{Cinchonidinyl(2-methacryloyloxyethyl)carbamate (CDMOC)}

A solution of MOI $(1.60 \mathrm{~g}, 10.0 \mathrm{mmol})$ in THF $(30 \mathrm{~mL})$ was added slowly to a solution of cinchonidine $(3.00 \mathrm{~g}, 10.0 \mathrm{mmol})$ and di- $n$-butyltin dilaurate (DBTDL) $(0.01 \mathrm{~g}, 0.016 \mathrm{mmol})$ in THF $(75 \mathrm{~mL})$ under nitrogen at r.t., and the solution was stirred for $48 \mathrm{~h}$ at $40{ }^{\circ} \mathrm{C}$. Water added to the reaction mixture, and the product was extracted with ethyl acetate. The combined organic layers were washed with water, dried over anhydrous $\mathrm{MgSO}_{4}$, and condensed under reduced pressure. The residue as solid was recrystallized from EtOAc to give CDMOC as white solid.

Yield 52\%, mp $143-144^{\circ} \mathrm{C},[\alpha]_{435}+0.7^{\circ}(c=1.0 \mathrm{~g} /$ $\mathrm{dL}, l=10 \mathrm{~cm}$, THF), ${ }^{1} \mathrm{H} \mathrm{NMR}\left(\mathrm{CDCl}_{3}\right) ; \delta$ (ppm from TMS) 8.88-7.39 (6H, quinoline group), $6.46(d, 1 \mathrm{H}$, $\mathrm{CH}$-quinoline group, $J=7.6 \mathrm{~Hz}), 6.04(\mathrm{~s}, 1 \mathrm{H}$, $\mathrm{CH}_{2}=\mathrm{C}\left(\mathrm{CH}_{3}\right)$ (trans) $), 5.83\left(\mathrm{~m}, 1 \mathrm{H}, \mathrm{CH}=\mathrm{CH}_{2}\right), 5.52$ 
(s, $1 \mathrm{H}, \mathrm{CH}_{2}=\mathrm{C}\left(\mathrm{CH}_{3}\right)($ cis $\left.)\right), 5.11(\mathrm{~m}, 1 \mathrm{H}, \mathrm{NH}), 5.00$ $\left(\mathrm{m}, 2 \mathrm{H}, \mathrm{CH}_{2}=\mathrm{CH}\right), 4.23\left(\mathrm{~m}, 2 \mathrm{H}, \mathrm{O}-\mathrm{CH}_{2}-\mathrm{CH}_{2}\right)$, $3.50\left(\mathrm{~m}, 2 \mathrm{H}, \mathrm{CH}_{2}-\mathrm{CH}_{2}-\mathrm{NH}\right), 3.34\left(\mathrm{~m}, 1 \mathrm{H}, \mathrm{N}-\mathrm{CH}_{2}-\right.$ $\mathrm{CH}_{2}$ (exo)), $3.06\left(\mathrm{~m}, 1 \mathrm{H}, \mathrm{N}-\mathrm{CH}_{2}-\mathrm{CH}\right), 3.00(\mathrm{~m}, 1 \mathrm{H}$, $\mathrm{CH}_{2}-\mathrm{CH}-\mathrm{N}($ exo $\left.)\right), 2.65\left(\mathrm{~m}, 1 \mathrm{H}, \mathrm{N}-\mathrm{CH}_{2}-\mathrm{CH}_{2}\right.$ (endo)), $2.54\left(\mathrm{~m}, 1 \mathrm{H}, \mathrm{N}-\mathrm{CH}_{2}-\mathrm{CH}\right), 2.26\left(\mathrm{~m}, 1 \mathrm{H}, \mathrm{CH}_{2}=\mathrm{CH}-\right.$ $\mathrm{CH}), 1.88\left(\mathrm{~s}, 3 \mathrm{H}, \mathrm{CH}_{2}=\mathrm{C}-\mathrm{CH}_{3}\right), 1.85\left(\mathrm{~m}, 1 \mathrm{H}, \mathrm{CH}_{2}-\right.$ $\left.\mathrm{CH}-\mathrm{CH}_{2}\right), 1.76\left(\mathrm{~m}, 1 \mathrm{H}, \mathrm{CH}-\mathrm{CH}_{2}-\mathrm{CH}_{2}\right.$ (exo)), 1.75 $\left(\mathrm{m}, 1 \mathrm{H}, \mathrm{CH}-\mathrm{CH}_{2}-\mathrm{CH}(\right.$ exo $\left.)\right), 1.55(\mathrm{~m}, 1 \mathrm{H}, \mathrm{CH}-$ $\mathrm{CH}_{2}-\mathrm{CH}_{2}$ (endo)), 1.51 (m, 1H, $\mathrm{CH}-\mathrm{CH}_{2}-\mathrm{CH}($ endo $\left.)\right)$ ${ }^{13} \mathrm{CNMR}\left(\mathrm{CDCl}_{3}\right) ; \delta$ (ppm from TMS) $167.3(\mathrm{O}-$ $\mathrm{C}=\mathrm{O}), \quad 157.9 \quad(\mathrm{NH}-\mathrm{C}=\mathrm{O}), \quad 149.8, \quad 148.4, \quad 145.8$, $130.2,126.7,126.1,125.8,123.4,118.7$ (in quinoline group), $141.7\left(\mathrm{CH}_{2}=\mathrm{CH}-\mathrm{CH}\right), 135.8\left(\mathrm{O}=\mathrm{C}-\mathrm{C}-\mathrm{CH}_{3}\right)$, 129.1 $\left(\mathrm{C}=\mathrm{CH}_{2}\right), 114.4\left(\mathrm{CH}=\mathrm{CH}_{2}\right), 74.3(\mathrm{C}$-quinoline group), $64.1\left(\mathrm{CH}_{2}-\mathrm{CH}_{2}-\mathrm{O}\right), 59.7(\mathrm{~N}-\mathrm{CH}-\mathrm{CH}), 56.5$ $\left(\mathrm{N}-\mathrm{CH}_{2}-\mathrm{CH}\right), \quad 42.2 \quad\left(\mathrm{~N}-\mathrm{CH}_{2}-\mathrm{CH}_{2}\right), \quad 40.3 \quad(\mathrm{CH}-$ $\left.\mathrm{CH}=\mathrm{CH}_{2}\right), 39.4\left(\mathrm{NH}-\mathrm{CH}_{2}-\mathrm{CH}_{2}\right), 27.6\left(\mathrm{CH}_{2}-\mathrm{CH}-\right.$ $\left.\mathrm{CH}_{2}\right), 27.4\left(\mathrm{CH}_{2}-\mathrm{CH}_{2}-\mathrm{CH}\right), 24.7\left(\mathrm{CH}-\mathrm{CH}_{2}-\mathrm{CH}\right)$, $18.2\left(\mathrm{CH}_{2}=\mathrm{C}-\mathrm{CH}_{3}\right)$

\section{Quininyl(2-methacryloyloxyethyl)carbamate (QNMOC)}

A solution of MOI $(1.40 \mathrm{~g}, 9.0 \mathrm{mmol})$ in THF $(30 \mathrm{~mL})$ was added slowly to a solution of quinine $(3.00 \mathrm{~g}, \quad 9.0 \mathrm{mmol})$ and di- $n$-butyltin dilaurate (DBTDL) $(0.01 \mathrm{~g}, 0.016 \mathrm{mmol})$ in THF $(46 \mathrm{~mL})$ under nitrogen at r.t., and the solution was stirred for $48 \mathrm{~h}$ at $40^{\circ} \mathrm{C}$. Water added to the reaction mixture, and the product was extracted with ethyl acetate. The combined organic layers were washed with water, dried over anhydrous $\mathrm{MgSO}_{4}$, and condensed under reduced pressure. The residue as solid was chromatographed on silica gel (EtOAc/MeOH-4/1) to afford QNMOC as white solid.

Yield 53\%, ${ }^{1} \mathrm{HNMR}\left(\mathrm{CDCl}_{3}\right) ; \delta$ (ppm from TMS) $8.73,8.00,7.47,7.38,7.35(5 \mathrm{H}$, in quinoline group), $6.43(\mathrm{~d}, 1 \mathrm{H}, \mathrm{CH}$-quinoline group, $J=7.6 \mathrm{~Hz}), 6.04$ (s, $1 \mathrm{H}, \quad \mathrm{CH}_{2}=\mathrm{C}\left(\mathrm{CH}_{3}\right)$ (trans)), $5.84 \quad(\mathrm{~m}, \quad 1 \mathrm{H}$, $\left.\mathrm{CH}=\mathrm{CH}_{2}\right), 5.53\left(\mathrm{~s}, 1 \mathrm{H}, \mathrm{CH}_{2}=\mathrm{C}\left(\mathrm{CH}_{3}\right)\right.$ (cis)), 5.12 $(\mathrm{m}, 1 \mathrm{H}, \mathrm{NH}), 5.02\left(\mathrm{~m}, 2 \mathrm{H}, \mathrm{CH}_{2}=\mathrm{CH}\right), 4.20(\mathrm{~m}, 2 \mathrm{H}$, $\left.\mathrm{O}-\mathrm{CH}_{2}-\mathrm{CH}_{2}\right), 3.96\left(\mathrm{~s}, 3 \mathrm{H}, \mathrm{OCH}_{3}\right), 3.47(\mathrm{~m}, 2 \mathrm{H}$, $\left.\mathrm{CH}_{2}-\mathrm{CH}_{2}-\mathrm{NH}\right), 3.33\left(\mathrm{~m}, 1 \mathrm{H}, \mathrm{N}-\mathrm{CH}_{2}-\mathrm{CH}_{2}(\right.$ exo $\left.)\right)$, $3.06\left(\mathrm{~m}, 1 \mathrm{H}, \mathrm{N}-\mathrm{CH}-\mathrm{CH}_{2}(\right.$ exo $\left.)\right), 3.00(\mathrm{~m}, 1 \mathrm{H}, \mathrm{N}-$ $\left.\mathrm{CH}_{2}-\mathrm{CH}\right), 2.66\left(\mathrm{~m}, 1 \mathrm{H}, \mathrm{N}-\mathrm{CH}_{2}-\mathrm{CH}\right), 2.60(\mathrm{~m}, 1 \mathrm{H}$, $\mathrm{N}-\mathrm{CH}_{2}-\mathrm{CH}_{2}$ (endo)), $2.27\left(\mathrm{~m}, 1 \mathrm{H}, \mathrm{CH}_{2}=\mathrm{CH}-\mathrm{CH}\right)$, $1.88\left(\mathrm{~s}, 3 \mathrm{H}, \mathrm{CH}_{2}=\mathrm{C}-\mathrm{CH}_{3}\right), 1.66-1.70(\mathrm{~m}, 2 \mathrm{H}, \mathrm{N}-$ $\mathrm{CH}_{2}-\mathrm{CH}_{2}$ (exo) and $\mathrm{N}-\mathrm{CH}-\mathrm{CH}($ exo $\left.)\right), 1.57(\mathrm{~m}, 1 \mathrm{H}$, $\mathrm{N}-\mathrm{CH}_{2}-\mathrm{CH}_{2}$ (endo)), $1.54(\mathrm{~m}, 1 \mathrm{H}, \mathrm{N}-\mathrm{CH}-\mathrm{CH}$ (endo)).

\section{Ethyl 1-oxo-2-indancarboxylate $(\text { EOIC })^{14}$}

Diethyl carbonate $(10.7 \mathrm{~g}, 91 \mathrm{mmol})$ in toluene $(5 \mathrm{~mL})$ was added to a suspension of $\mathrm{NaH}(\mathrm{ca} .60 \%$ in mineral oil, hexane washed, $1.44 \mathrm{~g}, 38 \mathrm{mmol}$ ) in tol- uene $(10 \mathrm{~mL})$ at $0^{\circ} \mathrm{C}$. To the mixture was added slowly a solution of 1 -indanone $(2.0 \mathrm{~g}, 15 \mathrm{mmol})$ at $0^{\circ} \mathrm{C}$, and the reaction mixture was stirred at r.t. for $2 \mathrm{~h}$. The reaction mixture was cooled to $0^{\circ} \mathrm{C}$, acidified with acetic acid, and poured into an ice- $\mathrm{HCl}$ mixture. The product was extracted with ethyl acetate. The combined organic layers were washed successively with aqueous $\mathrm{NaHCO}_{3}$ and brine, dried over anhydrous $\mathrm{MgSO}_{4}$, and condensed under reduced pressure. The residue was chromatographed on silica gel $(n$ hexane/EtOAc-4/1) and then purified by bulb-tobulb distillation to afford ethyl 1-oxo-2-indancarboxylate as pale yellow oil.

Yield $25 \%,{ }^{1} \mathrm{HNMR}\left(\mathrm{CDCl}_{3}\right) ; \delta$ (ppm from TMS) 7.35-7.79 (m, 4H, aromatic protons), $4.25(\mathrm{q}, 2 \mathrm{H}$, $\left.\mathrm{CH}_{2}-\mathrm{CH}_{3}, J=7.3 \mathrm{~Hz}\right), 3.72,3.70\left(\mathrm{dd}, 1 \mathrm{H}, \mathrm{CH}_{2}-\right.$ $\left.\mathrm{CH}, J_{\mathrm{gem}}=4.3 \mathrm{~Hz}, J_{\mathrm{vic}}=8.3 \mathrm{~Hz}\right), 3.59,3.53(\mathrm{dd}$, $\left.1 \mathrm{H}, \mathrm{CH}_{2}-\mathrm{CH}, J_{\text {gem }}=4.3 \mathrm{~Hz}, J_{\text {vic }}=8.3 \mathrm{~Hz}\right), 3.40$, $3.33\left(\mathrm{dd}, 1 \mathrm{H}, \mathrm{CH}_{2}-\mathrm{CH}, J_{\text {vic }}=8.3 \mathrm{~Hz}\right), 1.31(\mathrm{t}, 3 \mathrm{H}$, $\mathrm{CH}_{2}-\mathrm{CH}_{3}, J=7.3 \mathrm{~Hz}$ ).

\section{Polymerization}

Radical homopolymerization and copolymerization were performed with AIBN as initiator in a suitable solution in a sealed tube at $60^{\circ} \mathrm{C}$. After polymerization for $24 \mathrm{~h}$, the reaction mixture was cooled to $0{ }^{\circ} \mathrm{C}$. The polymer solution was poured into excess methanol to precipitate the polymer, and then separated by filtration. The polymer was purified by re-precipitation from THF-methanol systems twice. The polymer was dried in vacuo for $2 \mathrm{~d}$. The composition of copolymer was determined by ${ }^{1} \mathrm{H}$ NMR.

\section{Asymmetric Michael Reaction of $\beta$-ketoester to Meth- ylvinylketone}

A suspension of ethyl 1-oxo-2-indancarboxylate (EOIC), MVK and polymer-supported cinchona alkaloid ligands in toluene was stirred for $48-99 \mathrm{~h}$ at r.t. The reaction mixture was filtered. The filtered chiral catalyst was washed with toluene and then with methanol. The combined filtrate (the toluene and the methanol washings) was evaporated. The residue was chromatographed on silica gel ( $n$-hexane/EtOAc-4/1) to afford Michael adduct (ethyl 2-(3-oxo-butyl)-indan1-one-2-carboxylate) as pale yellow oil. Optical purity was determined by CHIRALPAK AD (n-hexane/2propanol $=9 / 1)$.

${ }^{1} \mathrm{HNMR}\left(\mathrm{CDCl}_{3}\right) ; \delta$ (ppm from TMS) 7.39-7.79 (m, $4 \mathrm{H}$, aromatic protons), $4.16\left(\mathrm{q}, 2 \mathrm{H}, \mathrm{CH}_{2}-\mathrm{CH}_{3}\right.$, $J=7.3 \mathrm{~Hz}), 3.66\left(\mathrm{~d}, 1 \mathrm{H}, \mathrm{CH}_{2}-\mathrm{C}, J_{\text {gem }}=17.5 \mathrm{~Hz}\right)$, $3.03\left(\mathrm{~d}, 1 \mathrm{H}, \mathrm{CH}_{2}-\mathrm{C}, J_{\mathrm{gem}}=17.5 \mathrm{~Hz}\right), 2.55(\mathrm{~m}, 2 \mathrm{H}$, $\left.\mathrm{CH}_{2}-\mathrm{CH}_{2}-\mathrm{C}=\mathrm{O}\right), 2.24\left(\mathrm{~m}, 2 \mathrm{H}, \mathrm{CH}_{2}-\mathrm{CH}_{2}-\mathrm{C}=\mathrm{O}\right)$, $2.13\left(\mathrm{~s}, 3 \mathrm{H}, \mathrm{O}=\mathrm{C}-\mathrm{CH}_{3}\right), 1.20\left(\mathrm{t}, 3 \mathrm{H}, \mathrm{CH}_{2}-\mathrm{CH}_{3}\right.$, $J=7.3 \mathrm{~Hz})$. 


\section{Measurements}

Gel permeation chromatography (GPC) measurement of the polymer was accomplished on a LC10AS (Shimadzu Corp.) equipped with a UV detector SPD-A (Shimadzu Corp.) and on a polarimetric detector OR-990 (Japan Spectroscopic Co., Ltd.) using $\mathrm{THF}$ as the eluent $50^{\circ} \mathrm{C}$. Four GPC columns HSG10, 15, 20, 40H (Shimadzu Corp.) were connected in series, and molecular weight was calibrated with standard polystyrene. Hg-line specific optical rotations were measured with a Jasco DIP-140 (Japan Spectroscopic Co., Ltd.) at $25^{\circ} \mathrm{C}$ (quartz cell length, 10 or $5 \mathrm{~cm} ; 1.0 \mathrm{~g} \mathrm{dl}^{-1}$ in THF). ${ }^{1} \mathrm{H}$ and ${ }^{13} \mathrm{C} \mathrm{NMR}$ spectra of the polymers were measured in chloroform- $d$ at r.t. in the presence of tetramethylsilane (TMS) as an internal standard using a JEOL EX-270 $\left({ }^{1} \mathrm{H}\right.$, $270 \mathrm{MHz},{ }^{13} \mathrm{C}, 68.7 \mathrm{MHz}$ ) spectrometer. Optical purity was determined by LC-10AT ${ }_{\mathrm{VP}}$ (Shimadzu Corp.) equipped with a UV detector SPD-A (Shimadzu Corp.) and CHIRALPAK AD (Daicel Chemical Industries, Ltd.). DSC measurement was accomplished on a DSC 3100 equipped with MTC 1000S (MAC Science Ltd.).

\section{RESULTS AND DISCUSSION}

\section{Syntheses of Chiral Monomer and Polymer-Supported Catalyst}

MOI having a reactive isocyanate group and a polymerizable double bond is easier to handle than acid chlorides such as mathacryloyl chloride under mild conditions. No by-products are formed by reactions of isocyanate group with alcohols or amines. Isocyanate group can easily react with a lot of compounds having active hydrogen. Many MOI derivatives have been synthesized from several alcohols and amines, and polymerized. ${ }^{12,13,15}$ The chiral RMOCs were prepared by the reaction of MOI with cinchona alkaloids in the presence of DBTDL in $c a$. $50-75 \%$ yields.

Radical homopolymerizations and copolymerizations with styrene (St) were performed with AIBN as initiator in a sealed tube at $60^{\circ} \mathrm{C}$. The crude poly- mers were reprecipitated to remove unreacted monomers. The results are summarized in Table I. The alkaloid contents of copolymers were determined by ${ }^{1} \mathrm{HNMR}$. Figure 1 shows ${ }^{1} \mathrm{HNMR}$ spectra of CDMOC and poly(CDMOC-co-St). Peaks assigned to a vinyl group for CDMOC at 6.04 and $5.52 \mathrm{ppm}$ disappeared after polymerization. Many kinds of chiral monomers and polymers using MOI have been reported in detail by authors. ${ }^{15}$

The obtained polymers were soluble in common organic solvents. The polymerization proceeded homogeneously. But after the polymer was dried in vacuo, the poly(CDMOC) was insoluble in various organic solvents except DMF. Number average molecular weights $\left(M_{\mathrm{n}}\right)$ of polymer were $2.6-11.8 \times 10^{3} . M_{\mathrm{n}}$ of CIMOC polymers tended to be larger than that of CDMOC polymers. We lately reported on polymerization of CIMOC and CDMOC in several organic solvents. ${ }^{15}$ The $M_{\mathrm{n}}$ of poly(CDMOC) obtained in DMF $\left(2.14 \times 10^{4}\right)$ was larger than that in THF $(7.3 \times$ $\left.10^{3}\right)$. It is difficult to clearly explain the reason, but polymerizations could be inhibited by steric hindrance of clusters formed hydrogen bond due to urethane segment of side chain.

Figure 2 depicts differential scanning calorimetry (DSC) curves of poly(CDMOC) and poly(CDMOCco-St) (run 4 and 5 in Table I). In the DSC curve for poly(CDMOC) (A), a endothermal peak due to melting was observed at $196^{\circ} \mathrm{C}$. However, no endothermal peaks due to phase transition for poly(CDMOC) were observed. On the other hand, there was a little difference DSC curves between poly(CDMOC) and poly(CDMOC-co-St). In DSC curves for poly(CDMOC-co-St), endothermal peaks due to glass transition temperature $\left(T_{\mathrm{g}}\right)$ and melting were observed at 89 and $242{ }^{\circ} \mathrm{C}$, respectively. The poly(CDMOC-co-St) exhibited a higher endothermal peak due to melting than poly(CDMOC).

Specific rotations $\left([\alpha]_{435}\right)$ of poly(CIMOC) and poly $(\mathrm{CDMOC})$ were $+84.0^{\circ}$ and $+0.72^{\circ}$ in THF, respectively. The specific rotation $\left([\alpha]_{435}=+54.4^{\circ}\right)$ of poly(CIMOC-co-St) was nearly in accordance with $[\alpha]_{435}$ calculated based on the content (wt $\left.\%\right)$ of the

Table I. Radical polymerizations of CIMOC $\left(\mathrm{M}_{1}\right)$ or CDMOC $\left(\mathrm{M}_{1}\right)$ with $\mathrm{St}\left(\mathrm{M}_{2}\right)$ in $\mathrm{THF}(1 \mathrm{~mL})$ at $60^{\circ} \mathrm{C}^{\mathrm{a}}$

\begin{tabular}{ccccccccc}
\hline Run & $\mathrm{M}_{1}$ & $\begin{array}{c}\mathrm{M}_{1} \text { in } \\
\text { monomer } \\
(\mathrm{mol} \%)\end{array}$ & $\begin{array}{c}\text { Polym. } \\
\text { time } \\
(\mathrm{h})\end{array}$ & $\begin{array}{c}\text { Yield }^{\mathrm{b}} \\
(\%)\end{array}$ & $\begin{array}{c}\mathrm{M}_{1} \text { in } \\
\operatorname{copolymer}^{\mathrm{c}} \\
\mathrm{mol} \%(\mathrm{wt} \%)\end{array}$ & $\begin{array}{c}M_{\mathrm{n}}{ }^{\mathrm{d}} \\
\left(\times 10^{-3}\right)\end{array}$ & $\begin{array}{c}M_{\mathrm{w}} / M_{\mathrm{n}}{ }^{\mathrm{d}} \\
{[\alpha]_{435}{ }^{\mathrm{e}}} \\
(\mathrm{deg})\end{array}$ \\
\hline 1 & CIMOC & 100 & 24 & 53.6 & 100 & 9.6 & 1.70 & 84.0 \\
2 & CIMOC & 20.2 & 9 & 34.1 & $26.1(60.4)$ & 11.8 & 3.22 & 54.4 \\
\hline 3 & CDMOC & 100 & 24 & 44.2 & 100 & 7.3 & 2.17 & $0.72^{\mathrm{g}}$ \\
4 & CDMOC & 20.0 & 24 & $32.0^{\mathrm{f}}$ & $19.7(51.4)$ & 2.6 & 1.76 & $8.0^{\mathrm{h}}$ \\
\hline
\end{tabular}

${ }^{\mathrm{a}}$ Initiator: $[\mathrm{AIBN}]=0.03 \mathrm{~mol} / \mathrm{L}, \mathrm{M}_{1}+\mathrm{M}_{2}=0.5 \mathrm{~g} .{ }^{\mathrm{b}} n$-Hexane insoluble part. ${ }^{\mathrm{c}} \mathrm{By}{ }^{1} \mathrm{HNMR} .{ }^{\mathrm{d}} \mathrm{By}$ GPC with standard polystyrene. ${ }^{\mathrm{e}} c=1.0 \mathrm{~g} / \mathrm{dL}, l=10 \mathrm{~cm}$, in THF. ${ }^{\mathrm{f}} \mathrm{MeOH}: \mathrm{H}_{2} \mathrm{O}=1: 1$ insoluble part. ${ }^{\mathrm{g}} c=1.0 \mathrm{~g} / \mathrm{dL}, l=10 \mathrm{~cm}$, in DMF. ${ }^{\mathrm{h}} c=1.0 \mathrm{~g} / \mathrm{dL}, l=5 \mathrm{~cm}$, in THF. 


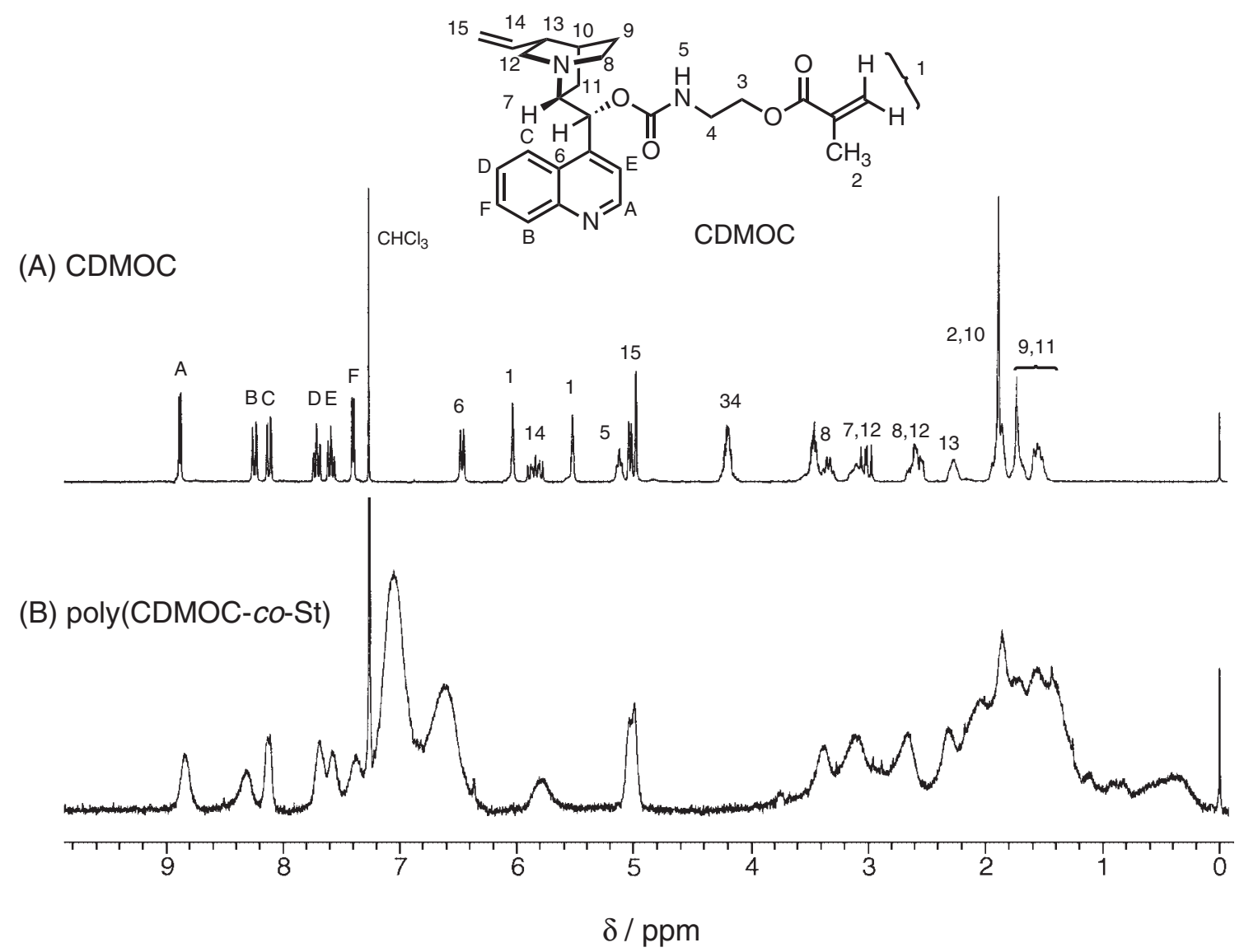

Figure 1. ${ }^{1} \mathrm{H} N M R$ spectra for $\mathrm{CDMOC}$ and poly(CDMOC-co-St) (run 4 in Table I) in $\mathrm{CDCl}_{3}$ at $23^{\circ} \mathrm{C}(270 \mathrm{MHz})$.

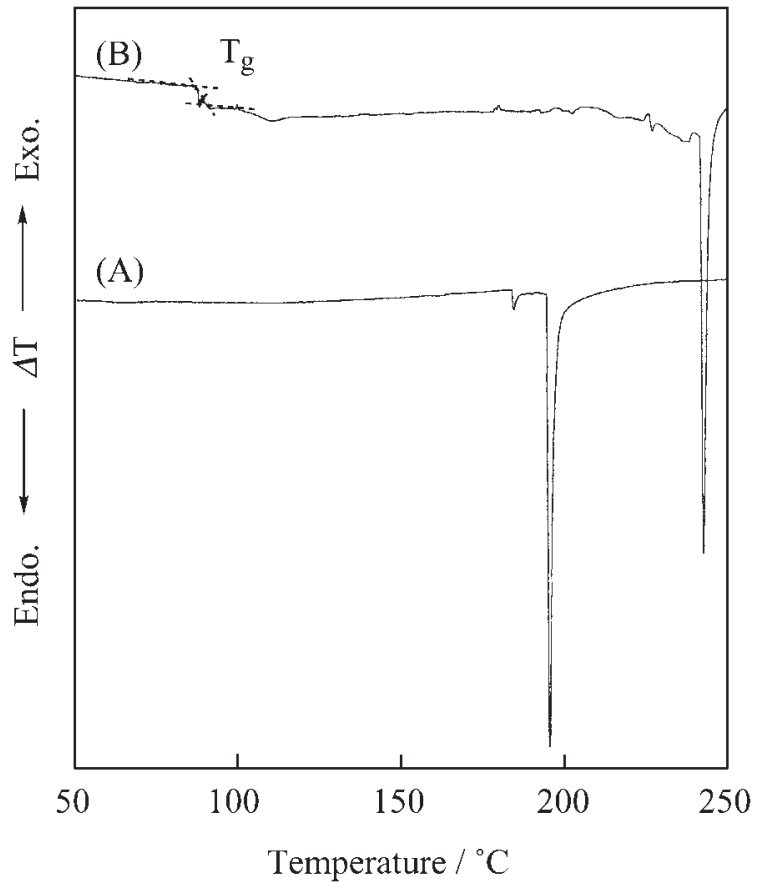

Figure 2. DSC curves for (A) poly(CDMOC) (run 3 in Table I) and (B) poly(CDMOC-co-St) (run 4 in Table I). Heating from 30 to $250^{\circ} \mathrm{C}$ at a heating rate of $5^{\circ} \mathrm{C} \mathrm{min}^{-1}$. monomeric unit of CIMOC in copolymer. We reported relationships between specific rotation $\left([\alpha]_{435}\right)$ and the content (wt\%) of poly(CDMOC-co-ST). ${ }^{15}$ Chiroptical properties of the copolymers were strongly influenced by the sequence of CDMOC and St monomer units.

\section{Asymmetric Michael Reaction}

The obtained polymers were tested for their efficiency in catalyzing the Michael addition of ethyl 1-oxo-2-indancarboxylate (EOIC) $)^{14}$ to MVK (Scheme 3). All reactions were carried out in toluene at r.t. After the reaction, polymer catalyst was recovered by filtration quantitatively and the adduct was isolated by column chromatography on silica gel. The changes in the composition and structure of the recovered polymer catalyst were not observed, judging from ${ }^{1} \mathrm{H} N M R$. The results of the reaction catalyzed by monomers and polymers are shown in Table II.

The enantio excess (\%ee) of the adducts was determined by chiral HPLC (CHIRALPAK AD). It was reported that the relationship between the absolute configuration of Michael addition and specific rotation $(R$-configuration $=$ dextro rotation $) .{ }^{16}$ The absolute configurations of major products obtained using poly- 
Polymer-Supported Cinchona Alkaloid Catalysts
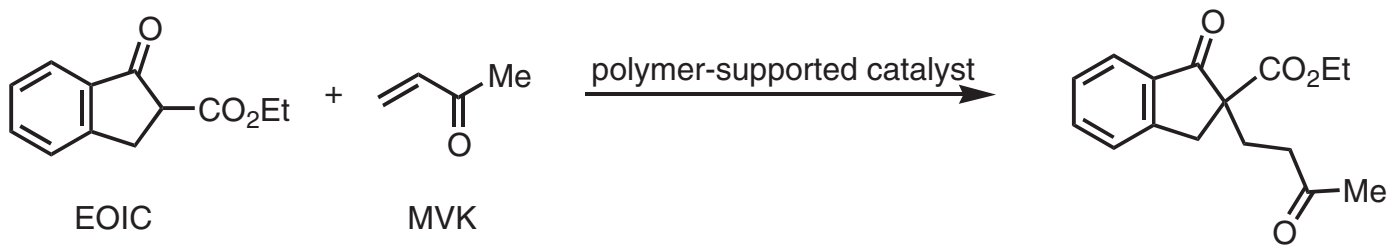

Scheme 3.

Table II. Enantioserective addition of methyl vinyl ketone to $\beta$-ketoester in toluene $(3 \mathrm{ml})$ at r.t. $^{\mathrm{a}}$

\begin{tabular}{|c|c|c|c|c|c|}
\hline Run & Catalyst & $\begin{array}{c}\text { Time } \\
\text { (h) }\end{array}$ & $\begin{array}{c}\text { Yield }^{b} \\
(\%)\end{array}$ & $\begin{array}{l}\text { e.e. }{ }^{\mathrm{c}} \\
(\%)\end{array}$ & Absolute config. \\
\hline 1 & CIMOC $^{\mathrm{d}}$ & 99 & 100 & 14.3 & $S$ \\
\hline 2 & poly $(\text { CIMOC })^{\mathrm{d}}$ & 48 & 100 & 13.3 & $S$ \\
\hline 3 & poly $(\mathrm{CIMOC}-c o-\mathrm{ST})^{\mathrm{e}}$ & 48 & 100 & 20.0 & $S$ \\
\hline 4 & $\mathrm{CDMOC}^{\mathrm{d}}$ & 72 & 40 & 10.3 & $R$ \\
\hline 5 & poly $(\mathrm{CDMOC}-c o-\mathrm{ST})^{\mathrm{f}}$ & 72 & 100 & 20.4 & $R$ \\
\hline 6 & QNMOC $^{\mathrm{d}}$ & 96 & 85 & 9.2 & $R$ \\
\hline 7 & $\mathrm{NaH}^{\mathrm{d}}$ & 2 & 100 & - & - \\
\hline
\end{tabular}

${ }^{\mathrm{a}}$ [methyl vinyl keton $] /[\beta$-ketoester $]=2 .{ }^{\mathrm{b}}$ Isolated yield. ${ }^{\mathrm{c}}$ Determined by CHIRALPAK AD $(n$-hexane $/ 2$ propanol $=9 / 1) .{ }^{\mathrm{d}}[$ Catalyst $] /[\beta$-ketoester $]=0.05 .{ }^{\mathrm{e}}[\mathrm{CIMOC}$ in copolymer $] /[\beta$-Ketoester $]=0.024 .{ }^{\mathrm{f}}[\mathrm{CDMOC}$ in copolymer $] /[\beta$-Ketoester $]=0.018$.

mer catalysts were assigned on the sign of specific rotations. Except for the reaction catalyzed by CDMOC monomer (Run 4), all reactions gave virtually quantitative chemical yields. Complexes of RMOC and its polymer were formed by hydrogen bonds to urethane segments. The complexes of CDMOC systems were rigider than that of CIMOC. The chemical yields drop because of a low basicity of a cinchona alkaloid group and steric repulsion. The $S / R$ ratios of adduct ranged from 57:43 to 40:60. The Michael adducts using poly(CIMOC-co-St) showed higher enantio excess (20\%ee) compared to those obtained by using nonpolymeric catalyst (CIMOC) and poly(CIMOC). The influence of methacrylate units of a non-polymeric catalyst was small because of the long distance between methacrylate units and the active site of catalysis. The reactions using poly(CDMOC) and poly(CDMOC-co-St) gave similar results. The stereoselectivity could be attributed to higher order structure in the presence of polymer matrix. The major products ( $S$-config) obtained using catalysts derived from cinchonine have the opposite configuration to the major products $(R$-config) obtained using catalysts derived from cinchonidine, which agrees with the result obtained in other reaction systems. ${ }^{17}$ For comparison, the catalytic behavior of monomeric alkaloid (QNMOC) prepared from quinine and MOI was investigated under similar conditions (Run 6). The adduct obtained with QNMOC catalyst gave 9.2\%ee ( $R$-config). Catalysts of cinchonine derivatives gave $(S)$-enantiomer in excess, while those of cinchonidine or quinine gave $(R)$-enantiomer in excess. Stereoselectivity of the asymmetric reaction is considered to be

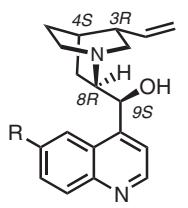

$\mathrm{R}=\mathrm{H}$ (Cinchonine; $\mathrm{Cl})$ OMe (Quinidine; QD)

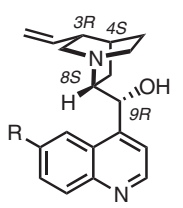

$\mathrm{R}=\mathrm{H}($ Cinchonidine $; \mathrm{CD})$ OMe (Quinine; QN)

Cinchona alkaloid

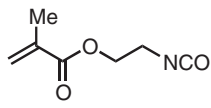

2-methacryloyloxyethyl isocyanate (MOI)

\section{Chart 1.}

(A)

(B)

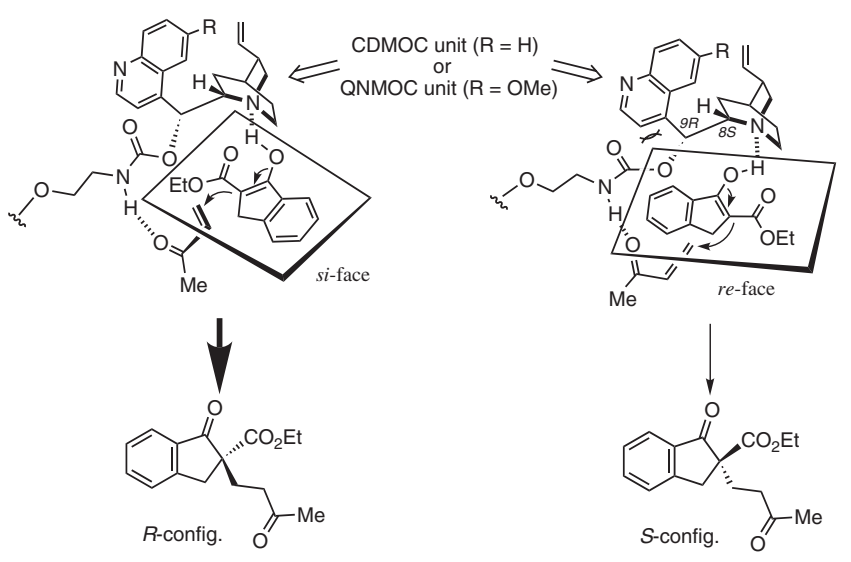

Figure 3. Two possible orientations of enolate in the transition states of the cinchonidine or quinine derivative-catalyzed addition to a methylvinylketone: (A) leading to $R$ enatiomer, (B) leading to $S$ enatiomer.

controlled by the configuration at C-8 and C-9 in cinchona alkaloid moiety (Chart 1). The transition state of asymmetric reaction is shown in Figure 3. The following steps are deduced: (1) the nitrogen of quinucli- 


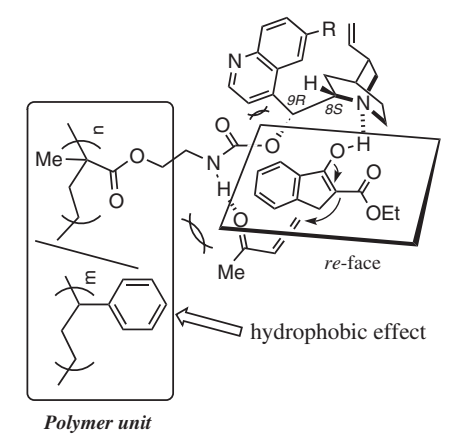

Figure 4. Effect of polymer unit on stereoselectivity.

dine in alkaloid takes a proton from the 1-indanone derivative and then an enolate is generated, (2) the carbamate group of the MOI-alkaloid catalyst holds MVK by a hydrogen bond to give a termolecular complex, (3) the rate-controlling addition of the enolate to the double bond of MVK occurs in two ways according to two possible orientations of enolate, (4) an addition from si-face of enolate using CDMOC unit to MVK to give ( $R$ )-config adduct (Figure 3A) or (4) an addition from $r e$-face of enolate using CDMOC unit to MVK to give $(S)$-config adduct (Figure 3B). Steric hindrance between the aromatic moiety of indanone and quiniline moiety of the catalyst makes the addition from the $s i$-face of enolate predominant, so that the $(R)$-enantiomer is produced in excess. The activities of polymeric catalyst increased with an increase of hydrophobic units as styrene. The observed increase in the enantio excess by copolymer is explained by the steric repulsion and/or hydrophobic effect of neighboring phenyl groups of styrene units on copolymer (Figure 4). The synthesis and application of copolymer obtained with RMOC and co-monomers are investigated in progress. In the cases of homopolymer, an addition of enolate to MVK chelated with neighboring alkaloid unit proceeds through $r e$-face attack to give an adduct (low enantio excess). The stereoselectivity of asymmetric reactions using a cinchona alkaloid is influenced by hydroxyl group at 9-position., ${ }^{70,11}$ The low stereoselectivity of the asymmetric reaction using RMOC and its polymer could be attributed to substituted carbamate group at 9-position. Further high stereoselectivites could be achieved by using some other bonding site at cinchona alkaloids with a polymerizable double bond unit, except hydroxyl group at 9-position.

\section{CONCLUSIONS}

Chiral methacrylates bearing a carbamate and a cinchona alkaloid group were easily synthesized from MOI and cinchona alkaloid. We prepared polymersupported chinchonine or cinchonidine derivatives, and applied them for asymmetric Michael reactions. The present results showed that the copolymer-supported catalyst was substantially more enantioselective than its monomeric analogue or homopolymer. The key feature of new catalyst may be due to the increased steric influence by the support on the cinchona alkaloids. Those polymers were found to be good nonmetal basic catalyst.

Further studies on synthesis and application of chiral poly(mathacrylate)s bearing urethane and quinine and quinidine are in progress.

Acknowledgment. The authors are thankful to Showa Denko K.K. for supplying the MOI. This work was partially supported by facilities of The Cosmetology Research Foundation.

\section{REFERENCES}

1. D. E. De Vos, I. F. J. Vankelecom, and P. A. Jacobs, Ed., in "Chiral Catalyst Immobilization and Recycling," WileyVCH, Weinheim, Germany, 2000.

2. For a recent review on the use of polymeric catalysts see: (a) Q.-H. Fan, Y.-M. Li, and A. S. C. Chan, Chem. Rev., 102, 3385 (2002).

(b) B. Clapham, T. S. Reger, and K. Janda, Tetrahedron, 57, 4637 (2001).

3. Review on the use of Cinchona alkaloids as organic catalysts: K. Kacprzak and J. Gawronski, Synthesis, 2001, 961.

4. (a) N. Kobayashi and K. Iwai, J. Am. Chem. Soc., 100, 7071 (1978).

(b) N. Kobayashi and K. Iwai, J. Polym. Sci., Polym. Chem. Ed., 18, 223 (1980).

(c) N. Kobayashi and K. Iwai, J. Polym. Sci., Polym. Chem. Ed., 18, 923 (1980).

(d) N. Kobayashi and K. Iwai, Macromolecules, 13, 31 (1980).

(e) N. Kobayashi and K. Iwai, J. Polym. Sci., Polym. Lett. Ed., 18, 417 (1980).

(f) N. Kobayashi and K. Iwai, Tetrahedron Lett., 21, 2167 (1980).

(g) N. Kobayashi and K. Iwai, J. Polym. Sci., Polym. Lett. Ed., 20, 85 (1982).

5. H. Danda, K. Chino, and S. Wake, Chem. Lett., 1991, 731.

6. P. Hodge, E. Khoshdel, and J. Waterhouse, J. Chem. Soc., Perkin Trans. I, 1983, 2205.

7. M. Inagaki, J. Hiratake, Y. Yamamoto, and J. Oda, Bull. Chem. Soc. Jpn., 60, 4121 (1987).

8. B. B. Lohray, E. Nandanan, and V. Bhushan, Tetrahedron Lett., 35, 6559 (1994).

9. L. Canali, C. E. Song, and D. C. Sherrington, Tetrahedron: Asymmetry, 9, 1029 (1998).

10. R. Alvarez, M.-A. Hourdin, C. Cavé, J. d'Angelo, and P. Chaminade, Tetrahedron Lett., 40, 7091 (1999).

11. V. Athawale and N. Manjrekar, Tetrahedron Lett., 42, 4541 (2001).

12. (a) Y.-K. Lee, Y. Nakashima, K. Onimura, H. Tsutsumi, and T. Oishi, Macromolecules, 36, 4735 (2003). 
(b) Y.-K. Lee, N. Hisamitsu, K. Onimura, H. Tsutsumi, and T. Oishi, Polym. J., 34, 9 (2002).

13. (a) Y.-K. Lee, K. Onimura, H. Tsutsumi, and T. Oishi, Polym. J., 33, 411 (2001).

(b) Y.-K. Lee, K. Onimura, H. Tsutsumi, and T. Oishi, Polym. J., 32, 1007 (2000).

(c) Y.-K. Lee, K. Onimura, H. Tsutsumi, and T. Oishi, J. Polym. Sci., Part A: Polym. Chem., 38, 4315 (2000).

14. H. O. House and C. B. Hudson, J. Org. Chem., 35, 647 (1970).
15. Y.-K. Lee, K. Yamashita, M. Eto, K. Onimura, H. Tsutsumi, and T. Oishi, Polymer, 43, 7539 (2002).

16. (a) M. Nakajima, Y. Yamaguchi, and S. Hashimoto, Chem. Commun., 2001, 1596.

(b) M. Nakajima, S. Yamamoto, Y. Yamaguchi, S. Nakamura, and S. Hashimoto, Tetrahedron, 59, 7307 (2003).

17. A. Sera, K. Takagi, H. Katayama, and H. Yamada, J. Org. Chem., 53, 1157 (1998). 